\title{
Identification, Current State and Development of Clusters in the Czech Republic
}

\author{
Josef Abrhám \\ Jan Herget \\ University of economics, Prague
}

\section{Doi:10.5901/mjss.2013.v4n11p144}

\section{Abstract}

The aim of the paper is to idenfity clusters currently existing in the Czech Republic and to analyze their regional dispersion, structure and activities. The analysis includes all currently active clusters to which it is possible to obtain relevant and compareable data. The data used in the study comes from specific cluster intitiatives, the database of the National Cluster Association of the Czech Republic a from the materials of the Ministry of Industry and Trade and from the agency specialized on the promotion of trade and investment, the Czechlnvest.

\section{Introduction}

The economic and price levels of the Czech Republic gradually converge to the European Union average, which fundamentally changes its competitive position in the international environment. The Czech economy will not be able to break through only via the price factor, but will have to develop those aspects of competitiveness that lead to the production of unique commodities and services based on a high degree of know-how and innovation. An important role is played by developed countries and in this regard, among other things, through cluster initiatives. On their basis emerged clusters positively affect productivity and availability of factors of production and create more accessible and cooperating suppliers, more efficient research and faster transfer of research results into practice.

In comparison with Western European countries, in the Czech Republic clusters and cluster initiatives are fairly new instruments. Over the last decade, there has been a strong boom of clusters, mainly due to the support of cluster initiatives provided from the EU resources. In the period after the accession to the European Union there were established more than seventy new cluster initiatives. A fundamental prerequisite for the establishment of new clusters were the activities of relevant state insitutions and the implementation of financial support. The formation of clusters, however, preceded properly done mapping studies and some clusters originated via the transformation or development of the alerady existing platforms of cooperating companies. Due to the rapid development in that area it seems to be necessary to regularly monitor and evaluate the current state of the development of cluster initiatives in order to continue targeting the instruments of cluster policies at national and regional level. The information about the state of cluster initiatives can also serve as a source of information for the relevant bodies of other countries of the European Union.

This paper reacts to the situation. The aim of the paper is to idenfity clusters currently existing in the Czech Republic and to analyze their regional dispersion, structure and activities. The analysis includes all currently active clusters to which it is possible to obtain relevant and compareable data. The data used in the study comes from specific cluster intitiatives, the database of the National Cluster Association of the Czech Republic a from the materials of the Ministry of Industry and Trade and from the agency specialized on the promotion of trade and investment, the Czechlnvest.

\section{Clusters in theoretical concepts}

In the theory of regional development we place information on clusters and aglomerations in the whole scope of the concept, which examines, above all, themes linked to the growth of poly-, aglomerative advantages, economic geography innovative systems, and so on. The first person to deal with the phenomenon of the territorial concentration of economic activities was the British economist M.A. Marshal; already at the end of the 19th century. He pointed to the so called industrial districts, which had a rather large amount of companies. According to Marshall, mutual interconnectedness brings the individual subjects advantages, mainly in the form of local savings [e.g., a greater supply of specialised workers, the availability of sub-supplier branches and services, support for the transfer of technology and 
knowledge between local firms and the like]. In addition to the above stated mechanisms, Marshall further mentions the operation of a certain atmosphere of reciprocity, to be precise, the creation of formal and informal contact, jointly shared customs, traditions, production and labour approaches and so on (Rysova,Dobrik, 2009). Other authors, besides A.Marshall have dealt with the reciprocal concentrations. G.Garforli considers industrial districts as an important source of competiveness. This all shows industrial districts to be one of the significant examples of the organisational form of post-Freudian flexible specialisation. Among their characteristic signs, according to the aforementioned, belong the following:

- A high level of the division of labour creates firm ties both within and outside the branch.

- A high amount of specialisation of production at firm level stimulates the accumulation of specialised knowledge and facilitates the integration of new technology.

- The creation of an efficient system of spreading information and knowledge at local level guarantees a rapid and effective transfer of technology between the participants.

- A high number of local participants leads to opportunities for seeking the best solutions as well as for examining research methods used by individual participants.

- Raising the level of relations between economic subjects has a favourable effect on the spreading of technological and organisational innovations, as well as increasing overall effictivity of the local production systems.

- The concentration of economic activities and increased use of technology influences the level of qualification of the workers (Rýsová, Dobrík, 2009).

Another view of the aglomerative effect can be found in the theory of field growth, which is connected with the work of F.Perrouxe. In the original Perrouxe version (Perrouxe, 1950), field growth is understood from a branch perspective. The author differentiates between the so called ,driving' and ,driven' branches. "He defined driving branches as rapidly developing branches, which are dominated by the big, constantly innovating firms, sending strong development impulses to their surroundings, that is, to firms in the driven branches so that they grow even faster than other, comparable firms" (Blažek, 2003)

The original growing fields theory underwent many modifications in the course of its development. The most important "interventions" which significantly enriched the theoretical framework are the theories of centres of growth and axes of growth (J.R.Boudeville). Boudeville, like Perroux, considers the motor of growth to be the developed [driving] branches, which contribute to the development of the connected [driven] branches. Perroux, however, does not include the effects of expansion with certain areas. Conversely, Boudeville presumes faster development of those regions which are localised driven branches, because it is calculated from the significant multiple effect of these branches on the rest of the economy of the region (Boudeville, 1966: 192).

We can put R.Baldwin and Ch.Wyplozse's publications among the modern approaches to the study of aglomeration and economic geography; in which the motives for the existence of aglomerative power are analysed. They argue that aglomerations get stronger "when the spatial concentration of economic activities form the motives which support further spatial concentrations"(Baldwin, 2008: 258). They define the main cause of aglomerative power as the so called ,demand and cost connection'. The demand connection is formed by the presence of a large market, which lowers trading costs. The cost connection is the availability of inputs [raw materials, plant and machinery, specialised services]; in other words, proximity to the supply chain. There exist, of course, opposing forces, the so called 'dispersal forces'(e.g., the price of land and realty, labour costs, strong competition), which work against the strengthening of the aglomerate. Spatial placement of economic activities, then, depend on the mutual interaction of aglomerative and dispersal forces (Baldwin, 2008: 258-259).

We can call the book of M.E.Porter (1990): „The Competitive Advantage of Nations" a pioneering work in the area of clusters. In this work, the cluster is defined as a "geographically close grouping of mutually interlinked firms and dependent institutions in a given discipline [e.g., even universities, scientific research institutions, chambers of commerce and the like], and firms in related fields which compete together, cooperate, have joint symbols and complement each other" (Porter, 1990: 157). Later on, M.E.Porter brought his original definition up to date and developed it like this: "Clusters are local concentrations of mutually linked businesses and institutions in a given field. Clusters include groups of interconnected industrial sectors and other subjects important for economic competition. They consist of, for instance, suppliers of specialised inputs and providers of specialised infrastructure. Clusters often expand vertically into marketing channels and customers, as well as horizontally to producers of complementary products and companies in industrial branches, related by virtue of skills, technology or joint inputs. Many clusters also include governmental or other institutions - such as, for instance, universities, standard setting agencies, research teams or business associations - 
which provide specialised training, education, information, research and technical support" (Porter, 1998: 78). Porter understands clusters as one of the main sources of microeconomic competitiveness. According to him, the main factor of competitiveness of a state or region is productivity, with certain used sources. Among the microeconomic requirements for the growth of productivity, Porter, in his current publication, includes: firms' performance and the refinement of their strategy, the quality of the microeconomic business environment and the level of development of the clusters.

Porter's concept was enriched and concretized by other authors as well as by major international and national organizations and institutions. Several definitions also published the European Commission. In the professional publication of the 2002 it characterizes a regional cluster as "a concentration of mutually interconnected and dependent companies under the same or similar industry, which works within a small geographic area." In the paper by the European Commission published in 2008 we can find an enhanced definition of the cluster saying: "A cluster can be defined as a group of firms, related economic actors and institutions that are located near each other and achieve sufficient potential for the development of commercial, technological and other cooperation. Clusters represent a real economic phenomenon that can be observed and measured." (European Commission, 2002: 14).

The definition according to the OECD is not limited to the regional level only. It states that a cluster concept can be applied at national, sectoral and company level. In terms of the content it emphasizes, besides developed ties between firms, also an importance of innovative elements and customers (OECD, 2007: 25-27).

Czechlnvest, which deals with the development of clusters in the Czech Republic, defines a cluster as "a set of regionally affiliated companies (entrepreneurs) and associated institutions and organizations - particularly tertiary education institutions (universities, colleges) - whose ties have the potential to strengthen and enhance their competitiveness." (Skokan, 2008: 291).

Ketels highlights the institutional aspects and the involvement of a broad group of stakeholders. "In the given concept the clusters consist of co-located and mutually interconnected industries, the engagement of government, academia, financial institutions and institutions for collaboration (specifically it means 5 players). Dynamic clusters are crucial for successful micro-environment." (Ketels, 2003).

S. A. Rosenfeld regards as essential for the successful functioning of the cluster its involvement in commercial exchanges, dialogue and communication. "Without the active channels of mutually interconnected companies there can no mutual local production and social prosperity, and therefore such an association cannot function as a cluster." (Rosenfed, 1997: 10).

Clusters and their influence on regional economic competitiveness are very relevant topics. Their significance grows in the context of globalisation of the world economy. Despite the unifying effect of globalisation, substantial differences between countries and regions from the point of view of specialisation, competitiveness and industrial dynamics exist. Competitive branches and industrial clusters can maintain their successful position in spite of the efforts of other subjects to imitate their activities. The most developed economies do not, in the international environment, set the price of the production factors, but they are forced to develop new forms of competitiveness. This concerns, mainly, such aspects of competitiveness which lead to the production of unique commodities and services based on a high degree of know-how and innovation. Among other things, cluster initiatives play a critical role in the developed economies in this regard.

Despite the fact that naturally born clusters exist for centuries and their formation is driven primarily by market factors, there has been prevailing in the recent decades, a positive view of the controlled and driven development of clusters in developed countries. In this context, various policies, programs and other tools to support the initiation and development of clusters are developed. Organized clusters are being called cluster initiative. From the literature we can give several definitions of cluster initiatives. According to Ketels a cluster initiative represents "organized efforts to increase growth and competitiveness of the cluster in the region, taking into account the involvement of cluster firms, government or research community ... Cluster initiatives are the grease that allows the engine of cluster dynamics to run at high speed." (Ketels, 2003: 8-9) The European Commission defines the cluster initiative very much like Ketels does and also adds that these initiatives generally stem from a formulated cluster policy and are usually conducted by specialized institutions (European Commission, 2008:62-64). As you can see, in the case of cluster initiatives, it is not only significant a concentration of firms, but also a created partnership and organized pursuit for the development of clusters, which is generally supported and developed externally through various public policies, programs and instruments. 


\section{Identification, structure and case studies of the functioning cluster initiatives}

Based on the mapping studies done, there were identified more than 70 newly formed cluster initiatives in the Czech Republic. Out of these initiatives 62 proved to be functional. The relevant information could be obtained in case of 46 clusters. The analysed sample therefore represents 46 cluster initiatives.

The identified clusters are distributed rather unevenly in terms of their location. Most clusters are located in the region Moravia-Silesia (12) and fewest, vice versa, in regions Prague (1) and Plzen (1). More than $50 \%$ of the clusters are located in three regions (Moravia-Silesia, South Bohemia and South Moravia).

In terms of the sectoral focus, the cluster initiatives include the following sectors: food industry, engineering, textiles, food processing, information technologies, mechatronics, plastics, peckaging, renewables, biotechnology, nanotechnology, tourism, biomedicine, etc. Most clusters are active in the sectors of information technologies (6), energetics (6) and wood processing industry.

Table 1: The overview of the examined cluster initiatives

\begin{tabular}{|c|c|c|c|c|c|}
\hline Cluster & Specialisation & $\begin{array}{c}\text { Number } \\
\text { of members }\end{array}$ & Cluster & Specialisation & $\begin{array}{c}\text { Number } \\
\text { of members }\end{array}$ \\
\hline ABC Wood & $\begin{array}{l}\text { wood processing, } \\
\text { lumbering }\end{array}$ & 7 & Czech Pellets & $\begin{array}{l}\text { wood processing, } \\
\text { manufacture of } \\
\text { wood }\end{array}$ & 54 \\
\hline $\begin{array}{c}\text { Security } \\
\text { Technology } \\
\text { cluster }\end{array}$ & $\begin{array}{l}\text { security } \\
\text { technology }\end{array}$ & 31 & $\begin{array}{c}\text { Czech } \\
\text { Nanotechnology } \\
\text { Cluster }\end{array}$ & nanotechnology & 13 \\
\hline Clutex & technical textiles & 26 & CGMC & general engineering & 75 \\
\hline Czech Stone Cluster & $\begin{array}{l}\text { cutting, shaping, } \\
\text { finishing of stone }\end{array}$ & 19 & Czech IT Cluster & $\begin{array}{l}\text { information } \\
\text { technology }\end{array}$ & 41 \\
\hline $\begin{array}{l}\text { Czech-Slovakian } \\
\text { Industry Cluster }\end{array}$ & $\begin{array}{l}\text { information } \\
\text { technology, } \\
\text { engineering } \\
\end{array}$ & 34 & $\begin{array}{c}\text { Czech } \\
\text { Communication } \\
\text { Cluster }\end{array}$ & $\begin{array}{l}\text { communication, } \\
\text { mobile, network }\end{array}$ & 51 \\
\hline CREA & $\begin{array}{c}\text { waterworks, } \\
\text { energy }\end{array}$ & 19 & IT Cluster & $\begin{array}{l}\text { information } \\
\text { technology }\end{array}$ & 12 \\
\hline Atomex Group & nuclear energy & 16 & Czech Bio & biotechnology & 37 \\
\hline $\begin{array}{l}\text { Czech Brewery } \\
\text { Cluster }\end{array}$ & $\begin{array}{c}\text { manufacture } \\
\text { of beer }\end{array}$ & 15 & ENVICRACK & $\begin{array}{c}\text { alternative energy } \\
\text { source }\end{array}$ & 28 \\
\hline ELECTRA-CITY & urban logistics & 23 & EKOGEN & $\begin{array}{c}\text { environmental } \\
\text { constructions }\end{array}$ & 16 \\
\hline HIT Cluster & $\begin{array}{l}\text { information } \\
\text { technology }\end{array}$ & 18 & IQ Cluster & $\begin{array}{l}\text { information } \\
\text { technology }\end{array}$ & 22 \\
\hline IT Cluster & $\begin{array}{l}\text { information } \\
\text { technology }\end{array}$ & 39 & ENERGO Cluster & energetics & 16 \\
\hline ERGOMED Cluster & $\begin{array}{l}\text { ergonomics, } \\
\text { prosthetics }\end{array}$ & 22 & $\begin{array}{c}\text { Cluster } \\
\text { BIOGAS }\end{array}$ & $\begin{array}{l}\text { manufacture of } \\
\text { industrial gases }\end{array}$ & 16 \\
\hline $\begin{array}{l}\text { Wood processing } \\
\text { Cluster - South } \\
\text { Bohemia }\end{array}$ & wood processing & 12 & $\begin{array}{l}\text { Vysočina } \\
\text { Precision } \\
\text { Engineering } \\
\text { Cluster }\end{array}$ & $\begin{array}{c}\text { manufacture of } \\
\text { machines and } \\
\text { equipment }\end{array}$ & 17 \\
\hline KLACR & tourism & 39 & NUTRIPOL & food industry & 15 \\
\hline $\begin{array}{l}\text { Cluster of Czech } \\
\text { Cabinet Makers }\end{array}$ & $\begin{array}{l}\text { manufacture of } \\
\text { furniture }\end{array}$ & 38 & $\begin{array}{c}\text { Cluster } \\
\text { Mechatronic }\end{array}$ & mechatronics & 14 \\
\hline OMNIPACK & $\begin{array}{l}\text { manufacture of } \\
\text { paperboards } \\
\text { products }\end{array}$ & 57 & Green Cluster & $\begin{array}{c}\text { waste management } \\
\text { services }\end{array}$ & 39 \\
\hline $\begin{array}{c}\text { Knowledge } \\
\text { Management } \\
\text { Cluster }\end{array}$ & entrepreneurship & 31 & $\begin{array}{l}\text { Moravian-Silesian } \\
\text { Energy Cluster }\end{array}$ & energetics & 21 \\
\hline $\begin{array}{l}\text { Moravian-Silesian } \\
\text { Automotive Cluster }\end{array}$ & $\begin{array}{l}\text { manufacture of } \\
\text { other parts and }\end{array}$ & 64 & $\begin{array}{l}\text { Moravian-Silesian } \\
\text { Wood- processing }\end{array}$ & wood processing & 28 \\
\hline
\end{tabular}




\begin{tabular}{|c|c|c|c|c|c|}
\hline & $\begin{array}{l}\text { accessories for } \\
\text { motor vehicles }\end{array}$ & & Cluster & & \\
\hline NANOPROGRES & nanotechnology & 20 & MedChemBio & biomedicine & 26 \\
\hline $\begin{array}{c}\text { Czech Machinery } \\
\text { Cluster }\end{array}$ & $\begin{array}{l}\text { manufacture of } \\
\text { machines end } \\
\text { equipment }\end{array}$ & 66 & $\begin{array}{l}\text { Network Security } \\
\text { Monitoring Cluster }\end{array}$ & $\begin{array}{l}\text { information } \\
\text { technology }\end{array}$ & 20 \\
\hline $\begin{array}{c}\text { Moravian Forest } \\
\text { Cluster }\end{array}$ & $\begin{array}{l}\text { forestry and } \\
\text { logging }\end{array}$ & 13 & NutriKlastr & food products & 23 \\
\hline $\begin{array}{l}\text { Regional Food } \\
\text { Cluster }\end{array}$ & food industry & 19 & Plastics Cluster & $\begin{array}{l}\text { manufacture of } \\
\text { plastics products }\end{array}$ & 34 \\
\hline Industrial Cluster & $\begin{array}{l}\text { manufacturing } \\
\text { industry }\end{array}$ & 11 & NIPAS & $\begin{array}{l}\text { low energy and } \\
\text { passive houses }\end{array}$ & 13 \\
\hline
\end{tabular}

Source: cluster initiatives

Strong clusters emerged in processing industries like machinery, precise and general engineering, technical textiles, plastics, packaging, or wood; in various technology areas like environmental technologies, biotechnology, renewables; nanotechnology or ICT (Ministry of Industry and Trade, 2013).

As regards the structure of the analysed clusters there prevail among cluster members the business entities (83 $\%)$, which are complemented in all the clusters by research institutions and universities. In some cases, there are also other intermediary institutions.

Coming to the examination of the objectives, activities and current projects undertaken of the Czech clusters, we find out that they concentrate primarily in the areas of supplier-customer relations, cooperation in the field of research and innovation, PR activities, export promotion and in the field of education. Most clusters focus on the business and research cooperation. Just one cluster is based only on the value chain of business relationships.

To illustrate the practical functioning of clusters is presented on the example of a few selected cluster initiatives in the Czech Republic in 2005-2012 in the text below. The case studies include Cluster of packaging manufacturers Omnipack and Cluster of Alternative energy sources ENVIRACK. Information about cluster are cited from web pages of cluster intitiatives (www.omnipack.cz; www.envicrack.cz).

The Omnipack cluster is focused on wrappings and packaging technology. The mission of the cluster is to increase the competitiveness and economic growth of the entrepreneurs in the field of packaging and logistics services by supporting their innovative activities. The main principles of that mission is transforming the knowledge of the research and development among the members of the cluster, strengthening of ties to scientific research and educational institutions, and systematic training of the members of the cluster. The aims of the activities of the Omnipack cluster is an extension of the existing infrastructure and a development of tools for the effective use of internal resources and capabilities of the cluster, and thus positively promote the economic growth and functional cooperation of the members. Goals and activities of the cluster:

- Development of standards of the OMNIPACK packaging technology

- Expansion of the development centre of the cluster.

- Streamlining the cooperation of its members via greater use of ICT.

- Promotion of innovative activities.

- Strengthening the links between $R \& D$ \& I, and industrial companies in the cluster.

- Support of the training of skilled labour in the cluster.

- Development of standards for strengthening ties between members of the cluster.

Cluster projects - examples:

- Technology centres of the Omnipack cluster - specialized development centres equipped with modern technologies for the development and testing of individual components of the OMNIPACK packaging system. CVD coordinates the use of TC and ensures the complexity of professional services (carrying out the required tests, including optimization of solutions and recommendations for further development).

- OMNIPACK packaging system - a set of studies of technical solutions of the innovations of individual components of the combined system including defined conditions for the successful transfer of innovations. The unique OMNIPACK packaging system unites technical specifications and procedures for the development projects of the cluster. Individual development projects of its members are aligned to these standards so as to 
obtain a reduction in development costs and improve the cost of innovation and their utilization.

- Centralized knowledge and information base - a comprehensive set of sector-focused and systematically obtained and classified information. The basis creates data from market research, patent searches, professional research of innovations and trends, technical data of the processes already realized (used for accelerating the innovation in the case of recurring activities), etc.

- Systematic development of human resources - a coordinated process of human resources management of the cluster in order to ensure a uniform level of knowledge and skills, which is a prerequisite for effective, common research and a source of continuous innovation activities of all members of the cluster. The Omnipack cluster implements a long-term program "The common system of HRD in the cluster".

Envicrack (cluster of alternative energy sources). The main activities of the cluster are focused on the use of alternative and renewable energy sources. The strategy of the cluster is to focus on research and development projects in the field of waste management and the use of alternative energy sources. Activities are designed to support its members in the implementation and commercial exploitation of research results in practice. Innovation strategy is based on an analysis of trends. Attention is focused on solving the problems of waste and reducing emissions while reducing costs associated with expenditures on energy consumption. After identifying the problem there is done the analysis of market size and the opportunity analysis. Research activities are concentrated primarily in the following areas:

- Pyrolysis technology for waste treatment.

- Solar energy - conversion of solar radiation into thermal and electrical energy.

- Innovation in rail transport - reducing energy consumption by using energy storage and recovery.

Cluster projects - examples:

- Acquisition of instrumentation and technical equipment for research and development of the energy storage the aim of the project is to build a mobile laboratory for measuring and evaluating the impact of storage units of electrical energy built on the use of the cooperation in various energy systems with renewable resources. The laboratory is equipped with the technology for energy storage and with the instrumentation and devices for measurement and evaluation of energy flows both inside and outside the laboratory. The laboratory equipment will be used to evaluate the time of the energy flows in response to the regime and to measure physical quantities for analysis, optimization and statistical analysis.

- Establishment of a testing laboratory for the development, measurement and testing of a concentrating solar power plant (CSP) designed to convert solar radiation into thermal and electrical energy - the construction of the test facility concentrating solar power (only one of its kind in the country) that will serve for the development, measurement and testing of the most advanced energy facilities, designed to convert solar radiation into thermal or electrical energy (or combinations thereof). Outcomes and conclusions from the pilot facility will be used to launch unique energy production facilities using renewable energy sources. The project will involve universities and the extended studying programs and emergence of scientific papers on the subject can be assumed.

- Research and development of a power units based on a Stirling engine to produce electricity and heat by concentrating solar energy - the goal of the project is the research and development of energy units based on a Stirling engine to produce electricity and heat transformation of concentrated solar energy electric power in the range 10-25 kW. Outcomes and conclusions from the pilot facility will be used to start the production of key parts of that unique facility using renewable energy sources for electricity generation - the Stirling Engine.

- Trial rail vehicle with energy optimization module - the goal of the project is to reduce the consumption of fossil fuels and the amount of $\mathrm{CO} 2$ and other fumes in the railway siding transport, the use of regenerated energy obtained during vehicle braking and traction while extending the life of batteries. The technology is applicable in the applications for rail vehicles and applications in public transport. The result of the project is to design fuzzy logic to optimize the operation super-capacitors including traction inverters, charging, management and use of reverse recovery energy recovery. The outcomes and conclusions from the pilot project will be used to begin production of energy-efficient rail traction vehicles.

\section{Conclusion}

Based on the analysis done it can be concluded that the activities of Czech national bodies combined with the use of the sources from the structural funds of the European Union stimulated, in the period between 2005-2013, an unusually 
dynamic development of cluster initiatives in the Czech Republic. With the emergence of new cluster initiatives in most cases a top-down approach with the bottom-up approach was combined. The origin of each cluster was preconditioned by the existence or creation of a platform of cooperating companies and other related institutions (especially higher education institutions or research organizations).

Based on the mapping studies done, there were identified more than 70 newly formed cluster initiatives in the Czech Republic. Out of these initiatives 62 proved to be functional. The relevant information could be obtained in case of 46 clusters. The identified clusters are distributed rather unevenly in terms of their location. More than $50 \%$ of the clusters are located in three regions (Moravia-Silesia, South Bohemia and South Moravia). As regards the structure of the analysed clusters there prevail among cluster members the business entities (83\%), which are complemented in all the clusters by research institutions and universities. In some cases, there are also other intermediary institutions.

Of course, in the future it will be essential to further develop the cluster instruments. We see reserves mainly in the nonexistence of some types of support and instruments. At the moment, the crossborder and international potential of the cluster branch is not used very much, and the role of regional actors is not fully appreciated, either. There does not exist any cluster programme at regional level in the Czech Republic, which would stress the precise needs of the given area. Regional operational programmes do not deal with certain issues. In order to develop a subsidy programme it would be good to also undertake a new mapping of potential cluster, and then to evaluate the performance of the new clusters. Find their weak and strong sides and present examples for the best practice. Furthermore, it would be helpful to examine the impact clusters have on the economic development of the region. Such and evaluation could serve a more precise concentration of the support provided. It would be possible to identify and support only specific areas, ort to evaluate the most successful clusters.

For further conceptions of the CR's cluster policy, we would consider it appropriate, also, to follow the current tendency in the orientation of cluster policy and instruments of the EU. It is planned to have more selective support for the chosen excellent clusters and to stimulate crossboarder reach and cooperation within the framework of the European Union. There should come into being globally competitive clusters, supporting the high level of specialisation of the European economy. As well, greater emphasis will be placed on measuring the performance and efficiency of the management of the clusters.

\section{References}

Baldwin, R., Wyplosz, CH. (2008): Ekonomie evropské integrace. Praha. Grada Publishing.

Blažek, J., Uhliŕ, D. (2003): Teorie Regionálního rozvoje, nástin, kritika, klasifikace. Praha. Univerzita Karlova - Nakladatelství Karolinum.

Boudeville, J. R. (1966): Problems of Regional Economic Planning. Edinburgh. Edinburgh University Press.

European Commission (2008): The Concept of Clusters and Cluster Policies and their Role for Competitiveness and Innovation. Luxembourg. Office for Official Publications of the European Communities.

European Commission (2002): Regional Clusters In Europe. Office for Official Publications of the European Communities. Luxemburg.

Ketels, Ch., Lundqist, G., Solvell, O. (2003): The Cluster Initiative Greenbook. Bromma Tryck AB. Stockholm.

Krugman, P. (1995): Development, Geography and Economic Theory. Cambridge. MIT Press.

Marshall, A. (1890): Principles of Economics. Macmillan and Co. London.

OECD (2007): Competitive Regional Clusters. Paris.

Ministery of Industry and Trade, Czech Republic (2013): Cluster Organisations in the Czech Republic. Prague.

Porter, M. (2004): Building the Microeconomic Foundations of Prosperity: Finding from the Business Competitiveness Index. In: The Global Competitiveness Report 2004-2005. Geneva. World Economic Forum.

Porter, M. (1990): The Competitive Advantage of Nations. London. Macmillan.

Rýsová, L., Dobrík, M. (2009): Úloha orgánov miestnej samosprávy pri podpore regionálneho rozvoja. Univerzity Mateja Bela v Banskej Bystrici.

Rosenfeld, S. A. (1997): Bringing business Clusters Into The Mainstream Of Economic Development. In: European Planning Studies. $5 / 1997$.

\section{Internet sources}

ABC Wood: www.abcwood.cz;

Atomex Group: www.atomex.cz;

Safety and Security Technology Cluster: www.btcluster.cz;

CGMC: www.maestroj.cz;

CREA: www.creacz.com; 
Czech Stone Cluster: www.czechstonecluster.eu;

Czech IT Cluster: http://www.czech-itc.cz;

Czech Bio: www.czechbio.org;

Czech Pellets: www.ceska-peleta.cz;

IT Cluster: www.ceskyitklastr.cz;

Czech Communication Cluster: www.projekt-mvno.cz;

ENVICRACK: www.envicrack.cz;

ELECTRA-CITY: www.electra-city.cz;

EKOGEN: www.ekogen.cz;

IT Cluster: www.itcluster.cz;

IQ Cluster: www.iqklastr.cz;

HIT Cluster: www.hitklastr.cz;

ENERGO Cluster: www.energoklastr.cz;

ERGOMED Cluster: www.ergomed.cz;

Wood processing Cluster - South Bohemia www.jcdk.cz;

KLACR: www.klacr.cz;

Cluster Biogas http://klastrbioplyn.cz;

Cluster of Czech Cabinet Makers: www.furniturecluster.cz;

Cluster Mechatronic: www.klastrmechatronika.cz;

NUTRIPOL: /www.nutripol.eu; www.kpsv.cz;

Vysočina Precision Engineering Cluster: www.kpsv.cz;

OMNIPACK: www.klastromnipack.cz;

Green Cluster: www.zelenyhorizont.cz;

Knowledge Management Cluster: www.kmcluster.cz;

MedChemBio: www.medchembio.cz;

Moravian-Silesian Automotive Cluster: www.autoklastr.cz;

Moravian-Silesian Wood- processing Cluster: www.msdk.cz;

Moravian-Silesian Energy Cluster: http://www.msek.cz;

Moravian Forest Cluster: www.lesnickyklastr.cz;

NutriKlastr: www.nutriklastr.cz;

Regional Food Cluster: http://rpklastr.mojedomena.cz. 